\title{
Handout or Hand up? A Social Entrepreneurship NGO Case in Mali
}

\author{
Dr. Warner Woodworth \\ Department of Management \\ Marriott School of Business \\ Provo, Utah, USA
}

\begin{abstract}
Drawing on more than three decades of action research and academic analysis, the narrative below summarizes years of work designed and carried out by a U.S.-based Non-Governmental Organization (NGO) laboring to raise financial resources and collaborate with rural villagers in one of the poorest regions within the impoverished country of Mali, West Africa. Academic disciplines drawn upon for this case include the social sciences, education and business. The thrust of this study includes microfinance, healthcare, education and literacy with a degree of emphasis on women's issues. It explores the country's challenges, the pursuit of several core strategies, andthe evolution of building an ecosystem for an improved quality of life and communal sustainability at the grassroots.
\end{abstract}

Key Words: Social Entrepreneurship, NGO, Mali, Ouelessebougou Alliance, Education, Healthcare

"The hyena chasing two antelopes at the same time will go to bed hungry." - Old Malian Proverb

Mali has been famous for centuries because of its historic site, Timbuktu, on the edge of the great Sahara Desert north of the land-locked nation's capital. Exploring, analyzing, and summarizing the results of 25 years of the author's work in social entrepreneurship through international development efforts in southern Mali in a region called "Ouélessébougou" is no easy task. My last trip to Africa was two years ago in which I traveled there to review and assess the work of an NGO that was established there in 1985, the Ouelessebougou Alliance (OA). It's an organization that's been developing an ecosystem for social change with which I've been involved off and on, including as a board member, consultant, and outside academic researcher laboring within the Koulikoro region of the country.

The cliché word "development" has morphed over the centuries. During the Enlightenment and into the times of colonization, colonial powers saw themselves as the bearers of 'development' as they sought to create societies around the world that mimicked their own. In more recent periods, experts have begun to alter this view by moving toward a more participatory process in which poor communities become partners rather than subjects.

Those engaged in development have begun to examine the process on a micro-level. In this rebirth, development has come to encompass Armartya Sen's view which states that development is "a process of expanding the real freedoms that people enjoy" (Sen, 1999, 3). In addition, other contemporary scholars have begun to foster homegrown development. William Easterly states "It is a fantasy to think that the West can change complex societies with very different histories and cultures into some image of itself. The main hope for the poor is for them... to borrow ideas and technology from the West when it suits them to do so" (Easterly, 2006, 28).

The Ouelessebougou Alliance has utilized the practices of social entrepreneurship for decades (Bornstein 2007, Lewis 2017), by establishing collaborative relationships between Utah citizens, academics and donors with the people of rural Mali. A major goal was that of building innovative partnerships between Utahns in the USA and people in the Ouelessebougou cluster of 40-plusvillages which together make up a commune or an arrondissement. It's an approach that brings Malian groups together and fosters local councils of indigenous men and women to strengthen one another. This organic, bottom-up approach has been growing in the non-profit world for decades. The following analysis examines a few of the social and economic impacts within the relationship between this Utah-based Ouelessebougou Alliance and the development of the Malian people; the organization's success, failures and future possibilities for growth. The Alliance is but one of a range of NGOs the author has designed, led, accelerated, or facilitated around the globe, seeking to empower U.S. citizens and college students while addressing extreme poverty in countries where oppression occurs (Smith and Woodworth, 2012).

\section{Overview of Mali and the Alliance}

The Republic of Mali is a landlocked country in the very heart of West Africa. It shares borders with Mauritania and Senegal to the west, Algeria to the North, Burkina Faso and the Côte d'Ivoire to the south, and Niger in the east. Mali's has a legacy French colonialism. Its 18 million citizens are heirs to a large number of cultural traditions, which in recent decades have been modified by modernization, urbanization, and the gradual conversion of indigenous religions to Islam which now reflects some 98 percent of the region (BBC, 2019; CIA, 2018). 
The French began to penetrate the county in the late 1800s concentrating efforts on occupying the interior of West Africa. As they marched inward, the military forces extracted Mali's resources, as well as eroded the traditional political structures and local leadership. The people eventually revolted and became independent in 1960 .

Less than a decade later, the first of several severe droughts began to plague Mali, interfering with the growth of crops, drying all rivers and causing fish to die. Between the years of 1972-1984 an estimated 100,000 people died due to starvation, and another 750,000 became heavily dependent on foreign aid. Despite international influence and collaboration with a range of humanitarian actors, droughts returned in 2009 with devastating additional effect.Mali were and is among the 25 poorest countries in the world. Into these realities, the Ouelessebougou Alliance was established in 1985 by Utahns seeking to assist an impoverished region of Africa. The organization promotes locally sustainable development in Ouelessebougou, Mali, an arrondissement south of the capital city of Bamako that encompasses seventy-two villages. This region claims a population of approximately 60,000 people with an agricultural based economy of millet, sorghum, rice, and corn grown for consumption, as well as cotton for export throughout Africa and some to Europe. In general, the Alliance raises between $\$ 160,000$ and $\$ 230,000$ per year for its programs.

Over the decades, the OA has worked with villages to address the most basic human needs. Jennifer Beckstead (2018), a former executive director of the Alliance, describes the progression of the organization when she states, "The first projects were to build wells for drinking water. Then, we realized they had no access to food, so we built irrigation wells. Then, we realized they had to deal with life-threatening yet preventable diseases, so we started vaccinations. We learned there was a strong connection between education and health, and in the 1990s, we started building schools. Later, we noted that if they had access to other resources, they could find better ways to help themselves."

The OA's basic ideas for social entrepreneurship were to identify the people's needs, design new strategies for learning, assist them in becoming healthier, and build local capacity so that further needs could be met. Thus, instead of a hand-out, OA seeks to offer a hand-up as the people gain greater control over their future.

Here is but one example of this approach to build resilience. Some years ago, as an OA board member and vice president, I was struck by the massive poverty in Mali and began to explore ways we could initiate new programs to generate family self-reliance and strengthen the economic grassroots of the region. I argued that we could await help from the federal government, hope for the United Nation's assistance for decades more, and pray for God to send the World Bank to come to the rescue. Or we could take action from below there in the grassroots amid the ugly realities of suffering and hunger. After some consideration, in response to the ever-present economic struggles faced by villagers, the Alliance's economic development sector was established by me and several students who I recruited from my own university and from Harvard. I raised money for this new initiative and after training my graduate students in the United States, the two students spent six months in Mali organizing a village bank.

After their doing a needs assessment, when I arrived there to officially assess things, we had 162 extremely poor individuals each pay $\$ 2$ to join the "Caisse," as it was called in French. We held elections to choose the three initial managers of our village microfinance bank, and while having a celebration, even Mali's president, who had warned us the plan would not succeed, suddenly drove into our compound with several jeeps full of rifle-bearing troops to announce he wanted to sign up as a member. The next morning we began training the new leaders and soon after started issuing microloans of merely $\$ 70$ each to qualified candidates. Of course, they were not like the big entrepreneurs in Europe or the U.S. Rather, they were those I referred to as "microentrepreneurs," "start-up entrepreneurs," or "necessity entrepreneurs." The majority were women so they could feed their humble families. We began to distribute small loans in to the villagers of Ouelessebougou and our efforts gradually expanded.

Eventually, OA reconstructed its program to offer revolving loans to villages for larger amounts and the program grew to fifteen villages. Since the reorganization, the Alliance has loaned well over $\$ 200,000$ to various communities. Each village established an Economic Development Committee formed by the village chief and is responsible for the creation of its business plan as well as maintaining a payment plan. In addition, these committees must participate in an annual business training conference to ensure their businesses will be successful. In these meetings, knowledge about business plans, loan management, repayment and business strategies are shared.

An Alliance assessment later concluded that only 33 percent of the villagers felt that their monthly income was sufficient to meet their needs. In order to improve this statistic and the harsh realities of everyday life, the OA provided $\$ 16,000$ in new village loans. Early on, some 91 percent of all loans were repaid or current. One of the unexpected benefits of our microfinance efforts has been that other Microfinance Institutions (MFIs) have moved into the arrondissement over time. 
This occurred after we had been warned by various government officials and development experts that the region was too impoverished, such that people could not create their own microenterprises and, if given tiny loans to start a business, they could never be able to repay such loans. But what happened instead is that OA's economic support succeeded, such that it became an attractive location for other NGOs to move into the area and set up their own bases of competition.

Below are several simple illustrations of the types of microenterprises established like the summarized cases that follow. Many loan recipients started tiny restaurants where they would cook simple meals to sell along the one highway passing through the region that took travelers from Bamako south some 600 miles to Côte d'Ivoire and its capital city Abidjan on the Atlantic coast. That was the principal route for outside traffic in the area, and such customers were largely the only folks with money to spend. Other microenterprises included women's shared vegetable gardens in which a group would establish a cooperative in which seeds were purchased, small plots of land were leased, and after the growing season, when produce was sold in the Ouelessebougou open market, the profits were shared collectively and equally. A third illustration was that of several women who with their microloans bought raw materials and metal vats to concoct liquid soap. Later, after treatment, and when the soap had hardened, they cut it all up into huge bars of soap to sell to mothers so that, for the first time, their families had hand soap for washing themselves and their children as a new approach to sanitation and better health.

Here's one final example of entrepreneurial initiative. It was based on a unique business venture that OA supported through microlending and gathering shea nuts which are native and abundant in Mali. The women in the Ouelessebougou region had the ability to manipulate the oil from these nuts into making shea butter which could then be solid on the international market, if the quality met sufficiently high standards. Shea is widely used in cosmetics as a moisturizer, salve or lotion by millions of women, not only in Mali or Africa, but globally. However, the high quality could only be extracted with the proper tools and training. So the Alliance provided training for 30 women to be educated by shea butter experts from the capital city of Bamako. With this knowledge, they improved their butter-making processes and enhanced the packaging, transportation, and marketing of their products.

With respect to how decisions like the microfinance cases described above occur, strategies and programs have arisen from various approaches. These, in turn, are managed by an Alliance team consisting of a Malian staff of five skilled Africans who operate all programs day-to-day on the ground in the Ouelessebougou area. They have extensive backgrounds in business and development, with three having some college-level education. In the U.S., the office is a two-person shop, supervised by a board of trustees with extensive management skills, social science graduate degrees from major universities, attorneys, and more. They are a highly committed group that gives of their time, energy, and family funds to oversee and coach the two country staffs, travel to Mali for oversight trips, and provide honest, open evaluation of programs and progress.

"The Organization's purpose is two-fold: 1) to work in partnership with village citizens to achieve their economic, health care, and education objectives, and 2) to provide the opportunity for both cultures to learn from other's family and social relationships. in partnership with local villagers to transform the quality of life in the Ouelessebougou region of Mali, West Africa by delivering sustainable programs in health and education" (OA Annual Report, 2019). Its fundamental design supports development that both originates and evolves within the existing cultural setting of Mali. "We want to empower them (the people of Ouelessebougou) to take ownership. We need a balance between them coming up with their own ideas and bringing in expertise from the outside" said Jodi Jensen, former program director (Wadley, 2009). With this overview, we turn to consider the two major and most long-lasting programs of the Alliance, healthcare and education.

\section{Village Healthcare}

Since its inception, Malian well-being has been a primary concern for the Alliance. Early on, the U.S. board and Malian staffers deliberated long and hard about how to improve the physical health of the people in that tough climate where everyone dwelled in mud huts with thatched roofs, having no electricity, paved roads, schools, or hospitals. Each year, the Mali staff and a Utah-based public health team would meet to strategize and provide a training seminar at the Alliance compound in Ouelessebougou where education and instruction is given based on the unique needs of each village. In recent years, OA has emphasized neo-natal resuscitation, water purification and nutrition. In line with the organization's mission to "work in partnership," OA established a "Health Village Workshop" back in 2005 and it still occurs today. In addition, early on the village chiefs formed Village Health Councils and the alliance has assisted them ever since in planning sessions to identify health priorities in the villages.

When the Alliance began in the mid-1980s, Mali suffered from an infant mortality rate of 145 per 1000 births, sixth worst in the world. So the Alliance developed, trained and worked with volunteer village health workers and midwives we recruited to teach basic hygiene and disease prevention. Currently, OA has provided ongoing training for hundreds of village health agents and midwives that began years ago, and the infant mortality rate is effectively down to less than half. Last year it was approximately 62 deaths per 1,000 live births (Macrotrends, 2020). 
Over the years, the OA has developed a relationship with the Malian government to provide vaccinations to the villages throughout the Ouelessebougou region. While the government claims to not have the means to provide needed vaccinations in general, it suggests specifically that it does not have the capacity to treat the most distant villages in far off rural communities.

So OA has itself been committed and able to assist and has provided more than 155,000 vaccinations for diseases such as polio, yellow fever, measles, tuberculosis, diphtheria, hepatitis A, vitamin A deficiency, the flu and tetanus. Thus far, OA villages have been able to vaccinate 92.8 percent of the children under five, and as a result, less than one percent of the children in Alliance villages now die from vaccine preventable diseases, a huge improvement.

The Alliance also works hard to provide mosquito nets, the best known malaria prevention technique. For several decades, the organization subsidizes the cost of the nets by selling them to the village families for $\$ 1$. Requiring a small fee is important, given our values that emphasize self-sufficiency. A core principle of OA's work is that nothing is free. We seek to not build dependency or to give "hand-outs." Rather, we focus on fiving a hand-up that will help people move toward a more sustainable future that they can control. A also provides health training with each net distributed because data suggest that consistent use decreases without proper education. Approximately half of all OA community adults and children consistently sleep under these treated nets. In 2017 approximately 1,200 new nets were distributed to villagers (OA Annual Report, 2018).

Another fundamental health goal of the Alliance is to provide clean water solutions for the Ouelessebougou region. Since its conception, the OA has dug more than 100 drinking and garden wells in collaboration with local villagers doing the labor, and using engineers for technical work. It's a social entrepreneurial partnership that yields concrete results. These wells decrease the appearance of diarrhea in children by more than 7 percent and have been correlated with fewer malaria incidents, as mosquitoes tend to avoid breeding in moving water sources.

For over a decade, OA funded and operated a simple pharmacy in the area's largest village that dispensed medicines, pain pills, health kits for families, and so forth. But in 2014 it was eventually discontinued because the Bamako government had sufficient resources to open its own official drug store in the area.

Another point regarding healthcare is that the Alliance requires its health workers to provide continuous information on preventative measures. A study by Brigham Young University researchers found that most OA health workers (47 percent) offered annual or semi-annual seminars on sanitary practices, disease prevention, and nutrition during public gatherings in all villages (BYU, 2009). As of a decade ago, at least, the data indicate that approximately eight percent of them provide weekly instruction, ten percent do so monthly, and 18 percent do this bi-monthly.

Finally, during my most recent field trip to Mali two years ago, I was struck by the big new hospital that was built and opened shortly before my arrival. In my mind's eve, I remembered the tiny, unsanitary "clinic" that had provided facilities for delivering a few babies and little more for decades. Many people went there only to die, to get away from their humble mud dwelling and away from their families where they suffered until passing away. With no electricity, it was dark and dungy, usually having no medical staff except when one might be sent from the capital for several days to attend the most critically ill.

So the reader may understand my great happiness in arriving with a U.S. medical team to be the first visiting specialists to enter Ouelessebougou's big, new, clean hospital that had recently opened. It came about because of the Alliance and one of our Malian staffers. Years earlier, I had recruited a young Malian named Yeah Samake as a translator on a trip to work in the region. Eventually, with the financial support of my friends, he was able to come to my university and earn a master degree in public management. Later we hired him on our staff in Mali, and then on our U.S. management team. After marrying and graduating, he returned to Mali and successfully entered politics hoping to use his Utah education to improve lives in Ouelessebougou. Ultimately he was elected mayor of the commune and went beyond that to campaign for national president. While that effort did not succeed, he obtained several offices in the national government and became Mali's ambassador to India and Indonesia.

With his political clout, Yeah was able to secure government funding for the building of a big new medical facility in Ouelessebougou. My colleagues and I were the first foreigners to use its facilities in serving poor villagers pro bono. Over the years earlier, we had taken groups of MDs to volunteer in Mali for week-long healthcare ventures. We had recruited, funded, and flown several Malian doctors from Africa to spend a semester at the University of Utah's highly ranked medical school with state-of-the-art facilities and numerous world class experts so they could return to West Africa with new expertise. On this trip, we had secured some $\$ 360,000$ worth of new high tech medical equipment for the new Ouelessebougou hospital so that we could not only do good work during our week in Mali, but so they would have considerable new equipment in order to offer better medical care long after we were to leave their nation. During that trip, our group of 22, four ophthalmologists and the rest being opticians, nurses, and technicians. 
The team performed four corneal transplants with eyes we flew onboard with us, the first in Mali's history. In addition, the team performed 107 cataract surgeries and did 1,087 eye examinations, distributing over 2,100 new pairs of glasses, all donated from U.S. friends and donors. The Alliance continues to make healthcare a vital element in its services. We now turn to the use of education as an Alliance tool for humanitarian services in Mali, the other thrust of our efforts.

\section{Education}

One of the most critical needs for development in many nations is the vital importance of public schools and education of the coming generations. This is particularly the case in West Africa where governments have little money and few schools, especially in rural regions beyond the capital cities. Mali's adult literacy rate is only approximately 35 percent (World Bank, 2020). With such low statistics, OA has made education a priority such that since the formation of the Alliance, there has been a dramatic increase in school enrollment.

One of the earliest tasks was to actually build schools so education could grow. Since 1985, some 42 schools have been constructed with Alliance funding and engineering expertise to ensure the buildings would last. In the first decade (1985-95), the few schools built were not well designed. They were made of adobe bricks that villagers would prepare, after which Alliance volunteers would arrive from America to help erect the buildings, put up thatched roofing, and make them as viable, yet inexpensive as possible. Seeing the gradual disintegration of those early structures due to heat, rain and faulty materials, as well as children's wear and tear, we determined that better solutions were needed. Over time, construction experts helped design and then manage teams of villagers in the erection of new schools using cinder block with cement floorings poured, metal roofing, steel doors and windows.

The national government had informed the communities that it did not have funding for impoverished Ouelessebougou. Instead, its money went toward supporting public schools in far-off Bamako. So our organization not only erected the schools, but convinced local chiefs and families they should raise their own funding to educate the next generation. Our objective was to ultimately have at least a single, one-room school house in each village accessible to the poorest families. Ignorance and illiteracy was too costly to ignore. So OA helped fund teachers using a simple formula that would gradually shift responsibilities from the NGO to the community. It would start with the time, energy and muscle of villagers to build their own humble school. Then the OA would fund the supplies and 100 percent of a teacher's salary for the first school year. He or she would relocate from Bamako to Ouelessebougou. For the second year, the Alliance would pay two-thirds of the cost, and the village contributed one third as their little microenterprises began to grow and generate more disposable income. In the third year, the formula was to supply two-thirds of the revenue from villagers, and one-third from OA. Finally, in the fourth year, local people were to finance a hundred percent of a school's operation so the Alliance could withdraw and shift its school construction money and energy to other villages where there still were no classrooms for children. This procedure worked very well as our strategy grew and became institutionalized and adequately funded.

In addition, after a school's completion, we sought to provide textbooks and decent furnishings for the buildings, with benches and roughhewn "desks" handmade by men of each village. These material necessities were funded at a hundred percent to begin with, and then it slowly tapered off as villages became more sustainable over time. In 2018 approximately 2,230 students attended schools where in prior times no formal education had been available. Another educational intervention by OA was that it has become receptive to community requests to install solar panels in the buildings of the elementary schools, to provide places for adults to take night class.

These education strategies have worked well over the years. After some two decades-plus, the organization stated that "since the inception of an Alliance education program... school enrollment has risen dramatically" (OA Annual Report, 2010). It has continued unabated ever since. The Alliance has been particularly pleased about the enrollment of females, which is 21 percent higher than the national school enrollment in Mali. As one villager stated, "Education is the key to success, it doesn't fix everything, but it gives you access to things and ability to progress" (ibid.). The Alliance has always had a strong commitment to gender issues, seeking to ensure that women and girls are primary beneficiaries of social innovation, which stresses education and health for females in striving for empowerment.

In 2005, the Malian government adjusted the national curriculum for first and second grades in order to require that teachers teach in Bambara, the nation's indigenous language. After that, beginning in third grade, French, Mali's official language, would start being taught. The Alliance was asked by the national government to pilot this program. Twenty-three teachers participated in training sessions organized by the Alliance to help assist with the difficult transition from the indigenous language (in first and second grades) so that students could be completely French-speaking by fifth grade as the new curriculum policies required.

It should be mentioned that OA's education programs have long-valued involvement from parents and the larger community. Thus, parents from the villages attend training sessions to learn how to become more active in their own children's education. 
Often, these parents are inspired to make sure teachers support the education of their daughters as well as ensuring that female enrollment continues to grow in the region. Unfortunately, Mali has often neglected its girls, usually explaining they are needed to help mothers at home with chores, cooking, cleaning and tending the younger kids of a family. It's a feeling of continuous pressure to conform to the centuries of chauvinism so prevalent in much of the world still today. In contrast, the Alliance seeks to gradually counter the oppression of females at all ages, and strives to create new opportunities for not only girls, but their mothers and single women in general.

Approximately a decade ago, the Alliance initiated a "sister-school" program which addressed an additional part of the organization's mission statement: "To provide the opportunity for both cultures (American and Malian) to learn from the other's family and social relationships" (OA: Mission Statement 2010) Since then, elevenU.S. schools in the state of Utah have been selected to partner with eleven schools in the Ouelessebougou region to exchange cultural experiences. A few American teachers have travelled annually to Mali to meet teachers there, observe customs, record music and stories which they then take home to teach and inspire their Utah students and build global appreciation and mutual understanding.

One final aspect of this NGO's educational development strategy is that of creating a "Lead Teachers" program. It's another aspect of the OA education process which is quite unique. The organization has established and funded Lead Teachers, selected because of their excellent teaching skills, who receive yearly training and a small stipend to coach other teachers in certain schools within the region. These Lead Teachers are required to make monthly visits to each school to follow-up on training and provide constructive feedback for future program improvements.

\section{Conclusion}

Clearly, the Ouelessebougou Alliance is not a utopia. There is still too much poverty and a great deal of malnourishment even though people's diets and nutrition are improving. While more schools are being built, education is woefully underfunded and the quality of learning will require both many more francs and dollars.

As I wrap up this case, people around the globe are embroiled in the horrific devastation of the Coronavirus pandemic. Worldwide there are 16,418,867 Coronavirus cases globally and 652, 256 deathsas of this very hour (Worldometer, 2020). The crisis is hitting the United Sates hard, resulting as of today, in some 4.4 million cases and 150,000 deaths. In Mali, so far, there are but 2,500 cases of the disease with 123 deaths. But, of course, each one is tragic, each individual, each family, each village, each region. For the Alliance, the U.S. toll is shaking the American economy which means, if it continues much longer, OA supporters will not be traveling to volunteer in Mali, nor will the donations for the NGO's operations continue at recent levels to support the people of Ouelessebougou in the future like they have in past decades. What this means for the long-term is unclear.

In summing up the social impacts of the Ouelessebougou Alliance and the people it serves, we see that development through social entrepreneurship is a multi-faceted process that incorporates all aspects of human wellbeing. Perhaps the words of the Malian managing director of the Alliance, Anounou Sissoko, offered a holistic vision a few years ago when he commented: "Development is a multi-aspect. It is the human being complete"(Ward, et al, 2008, 475). When he and I jointly presented the NGO work of OA to a large crowd in Utah when he was in town for a board meeting recently, he affirmed this, telling people that without a holistic methodology, development will only be a piecemeal process when what is required is evolution toward comprehensiveness (Sissoko and Woodworth, 2018).

The narrative of the Alliance is not one about top down control, as is the case with many NGOs and development institutions. In this instance, it's more of a reciprocal relationship in which African needs are identified, Utah resources are available, and mutual exchanges are made. Both groups, the Utahns and the Malians, have established innovative networks using social entrepreneurial values such as shared passion, inventing new methods, cooperation, and joint problem-solving. Expertise is shared, mutual respect and love develops, and lives are enriched on both sides of the world.

For example, on my most recent trip to Mali in 2017, I was one of 22 U.S. experts with various health and development backgrounds, all committed to reduce African suffering. They were mostly trained in medicine with the majority being ophthalmologists who do surgery, or optometrists who diagnose vision problems and prescribe new eyeglasses. With each paying their own expenses, our group tested the vision of some 2,100 villagers and gave them new glasses. The team examined 600-plus patients and performed 162 cataract surgeries, restoring the ability to see for many individuals, from age 23 to 105 . The top MDs also transported corneas in our carry-on bags and performed four corneal implants, the first in Mali's history, an accomplishment heralded by the country's Minister of Health, leading to a banquet of appreciation at the end of our work, one of a few formal signs of appreciation in Alliance history. 
In field interviews during those weeks in Ouelessebougou in November 2017, the general consensus I heard from the Malians was one of appreciation for what Utahns have done to design and execute a long term development model that stays focused in this one area, the villages of the Ouelessebougou arrondissement. On the other side, from the American visitors, the feeling was similar in that they expressed how much they learned from the women and men of Ouelessebougou. As an MD told me, seeing the people's strength in abject poverty, their dignity in gradually overcoming hardships, was inspiring.

He saw much improvement since his previous trip four years earlier. OA has stayed grounded in the belief that collaboration and joint decision-making is an effective method for gradual improvement in a village's quality of life.

During my last work there, a group of old village elders in a rural cluster of mud homes and thatch roofs told me, they have witnessed incremental improvements during over three long decades from Americans of the Alliance in the West African lives of themselves, their children and grandchildren. In comparison with other areas of Mali, Ouelessebougou is gaining in better education and improved health as it facilitates an ever-expanding social ecosystem. While several other NGOs over the years had their groups go into Mali and soon move on elsewhere, OA has stayed focused on achieving long-term, in-depth impacts. The elders felt that the Alliance seems to believe in a concept of development as one that includes growth and progress accomplished through the realization of individual potential, along with building and strengthening of social relationships. In another village, one person in a group of women leaders suggested that to her development is when health and literacy improve so that selfsufficiency is strengthened. "Then I think that this country is developed."

To conclude, I recall the words of my old Malian warrior friend, Modibo Diarra, who helped lead the 1960 revolution to overthrow the French colonizers and would later be hired as our Executive Director for the Ouelessebougou Alliance. One evening as I sat with him under a huge mango tree in a village, he declared: "We learned much from the outside world, including ideas from Europe and America. But to fully develop Mali, we must walk our own pathway through the villages of Africa."

\section{References}

BBC. 2018. Mali country profile. http://www.bbc.com/news/world-africa-13881370. Feb. 19.

Beckstead, J. 2018. Author's interview notes). May 7.

Bornstein, D. 2007. How to Change the World: Social Entrepreneurs and the Power of New Ideas. Oxford: Oxford University Press.

BYU. 2009. Field Study of Ouelessebougou Impacts in Mali, West Africa. Unpublished report.

CIA. 2019. World Factbook.https://www.cia.gov/library/publications/the-world-factbook/geos/ml.html.

Easterly, W. 2006. The White Man's Burden: Why the West's Efforts to Aid the Rest Have Done So Much Ill and So Little Good. Oxford: Oxford University Press.

Kahn,B. 2011. "Informing Farmers and Combating Drought in Mali." Earth Institute, Columbia University. http://blogs.ei.columbia.edu/2011/04/13/informing-farmers-and-combatting-drought-in-mali/, April 13.

Lewis, J. 2017. The Unfinished Social Entrepreneur. Franklin, NC: Red Press.

Macrotrends. 2020. Mali Infant Mortality Rate 1950-2020. https://www.macrotrends.net/countries/MLI/mali/infant-mortality-rate.

Ouelessebougou Alliance. 2010, 2013, 2019. Annual Reports. https://www.lifteachother.org/about-us/.

Sen, Amartya. 1999. Development as Freedom. New York: Alfred A. Knopf.

Sissako, A. and Woodworth, W. 2018. The Vibrant Ecosystem of Social and Economic Development in West Africa. A social entrepreneurship seminar to the Provo, Utah community, May 7, 2018.

Smith, I. H. and Woodworth, W. P. 2012. Developing Social Entrepreneurs and Social Innovators: A Social Identity and Self-Efficacy Approach. Academy of Management Learning and Education (AMLE). Vol. 11, No. 3, 2012, pp. 390-407.

UNICEF. 2017.http://www.unicef.org/infobycountry/mali_statistics.html.

Wadley, C. 2009. "Journey of Hope." Deseret News.Quote is by OA staffer, Jodi Jensen. http://www.deseretnews.com/article/705288344/Journey-of-hope.html?pg=1, March 3.

Ward, C. et al. 2008. BYU Mali Study. Women's Research Institute, Provo, Utah.

Woodworth, W. 2018. Seminar discussion at the Association for Research on Civil Society in Africa (AROCSA), Cairo, Egypt, July 26-28, 2018.

World Bank. 2019. Literacy rate, adult total forMali.https://data.worldbank.org/indicator/SE.ADT.

Worldometer. 2020. COVID-19 Coronavirus Pandemic. July 26.https://www.worldometers.info/coronavirus/. 